\title{
Towards A Sound NeW ZEALAND INTELLECTUAL PROPERTY LAW
}

\author{
Susy Frankel
}

This article discusses aspects of New Zealand's intellectual property law and policy. The author examines New Zealand's existing laws and international obligations. The author proposes that New Zealand develop a sound law of intellectual property that honours the Treaty of Waitangi and is of benefit to New Zealanders. She considers a number of aspects of New Zealand's international obligations and demonstrates how New Zealand can develop laws that assist New Zealanders in the fields of science and technology, business and the arts and not contravene our international commitments. The article concludes that New Zealand's intellectual property law should be founded on policies that enhance the development and use of knowledge based assets for New Zealanders.

\section{INTRODUCTION}

New Zealand has a number of intellectual property statutes and some intellectual property rights which are not based on statute, but rather are common law doctrines.

Commentators often group intellectual property law into three broad categories: copyright, trade marks and patents. Using those three broad categories I group New Zealand's current intellectual property statutes and common law doctrines as follows:

\begin{tabular}{|l|l|l|}
\hline $\begin{array}{l}\text { Copyright } \\
\text { and related rights }\end{array}$ & $\begin{array}{l}\text { Trade marks and related } \\
\text { rights }\end{array}$ & Patents and related rights \\
\hline Copyright Act 1994 & Trade Marks Act 1953 & Patents Act 1953 \\
Designs Act 1953 & $\begin{array}{l}\text { Geographical Indications } \\
\text { Act } 1994^{1}\end{array}$ & $\begin{array}{l}\text { Plant Variety Rights Act } \\
\text { Layout Designs Act 1994 }\end{array}$ \\
Breach of confidence & Passing off & Breach of confidence \\
\hline
\end{tabular}

* Senior Lecturer in Law, Victoria University of Wellington.

1 As at February 2001 the Geographical Indications Act 1994 has still not been brought into force by Order in Council. 
The framework of New Zealand's intellectual property laws is in part attributable to a history of adopting, virtually wholesale, the United Kingdom's equivalent laws. In addition, New Zealand is a member of a number of international conventions and treaties. These international obligations have helped to shape New Zealand's intellectual property policy. This article explores whether there has been a consistent or policy driven approach to New Zealand's intellectual property law.

In this article I summarise New Zealand's domestic and international obligations. I then consider each area of intellectual property law and the policies behind them. I recommend some policy changes. All of the suggestions I make are with the aim of framing intellectual property law to assist New Zealand's scientists, artists and businesses which create and use intellectual property products, while keeping in line with New Zealand's international obligations.

It is not my intention to produce a road map for reform, rather to raise some issues in relation to the intellectual property policy making process.

\section{THE SCOPE OF NEW ZEALAND'S INTELLECTUAL PROPERTY LAWS A Adopting United Kingdom Statutes}

New Zealand has adopted a number of United Kingdom statutes, but it has done little to consider the appropriateness for New Zealand of the policies that drive those statutes. Economic conditions which play a major part in the direction of intellectual property law, are not the same in the United Kingdom and New Zealand. In particular, the levels of production and use of intellectual property assets are likely to be significantly different in an economy of the scale and type of the United Kingdom. This importation of United Kingdom statutes has not been entirely wholesale. Our legislative drafters have made a few changes. However, where New Zealand has modified the United Kingdom statutes it is frequently difficult to discern any deliberate policy motivations behind the differences.

For example, the Copyright Act 1994 requires all categories of work to be original. This includes films sound recordings, broadcasts, cable programmes and typographical arrangements of published editions. ${ }^{2}$ The United Kingdom Act on which the 1994 Act was based only requires originality in respect of literary, dramatic, musical and artistic works. ${ }^{3}$ New Zealand's Copyright Act 1962 also only required originality for literary, dramatic, musical and artistic works. ${ }^{4}$ The Copyright Act 1994 provides no guidance on what this

2 Copyright Act 1994, s 14(1).

3 Copyright, Designs and Patents Act 1988 (UK), s 1(1).

4 Copyright Act 1962 (repealed) Part I Copyright in Original Works and Part II Copyright in Other Subject Matter. 
new application of originality means. There is no discussion of it in any Select Committee report or Hansard. The absence of such a discussion suggests that Parliament did not intend a dramatic change of policy. Yet it is not clear what standard of originality Parliament intended films, sound recordings, cable programmes broadcasts and typographical arrangements of published editions should meet. It is likely that a low standard of originality would be required for these works. By a low standard I refer to one that allows labour or sweat of the brow devoid of creativity, to meet the originality requirement. ${ }^{5}$ Unless a low standard of originality is applied many films, sound recordings, broadcasts, cable programmes and typographical arrangements would not be protected by copyright, for want of originality. The potential difficulty is illustrated if one imagines the facts of Hyde Park $v$ Yelland ${ }^{6}$ occurring in New Zealand. There the notorious newspaper The Sun published security camera stills showing the late Diana Spencer's arrival and departure time at the Villa Windsor - the place where Dodi Al Fayed's father claimed the couple intended to settle down together. The English High Court and the court of Appeal held that copyright subsisted in the security camera stills as films. The main issues were whether The Sun's use of the stills was fair dealing, or in the public interest. The High Court held there was fair dealing and it was in the public interest. The Court of Appeal overturned these findings. While celebrities of such status are not frequent travellers to our shores what is conceivable is that security camera film could be the subject of a copyright debate here. Suppose a Minister of the Crown is caught on video leaving a place he or she has publicly claimed never to have visited. Could the maker of that video assert copyright over it. In order to be the subject of copyright the film must be original. What would make such a film original? If the security camera was set up to film the same spot continuously and much of its recording is mundane does the fact that the exact same film has never been recorded before establish originality? Or is originality established because there was skill in establishing the right camera angle for the relevant spot to be filmed? If such films are not protected by copyright then this would be a significant change of policy. Such films were protected under the 1994 Act's predecessor, the Copyright Act

5 Broadly, a plaintiff establishes a work is original by showing the creation of the work involved skill, judgement or labour: Ladbroke v William Hill [1964] 1 All ER 465. Subsequent case law has arguably accepted labour alone as adequate to establish orginality, see Waterlow Directories Ltd $v$ Reed Information Services Ltd [1992] FSR 409 and Elanco v Mandops (Agrochemical Specialists) Limited [1980] RPC 213. The United States Supreme Court in Feist Publicaitons v Rural Telephone Service Co (1991) F 113 L Ed 2d 358 required a modicum of creativity to exist in order to establish originality. New Zealand has never adopted the modicum of creativity requirement and arguably has proceeded on the labour alone path, see Susy Frankel "'Originality' Still a Matter for Debate in New Zealand' (1997) 1 NZIPJ 242. 
1962. ${ }^{7}$ On the other hand, if no change was intended what did Parliament intend by prefacing all the categories of work as requiring originality? The only answer can be a low threshold for originality.

\section{B International Agreements}

New Zealand is a member of a number of international agreements governing standards of intellectual property law. In late 1994 New Zealand rushed to incorporate the Trade Related Aspects of Intellectual Property Rights Agreement (TRIPs) ${ }^{8}$ agreement into its law. ${ }^{9}$ This rush to ensure Treaty compliance stands out from the law makers' approach towards implementing a number of World Intellectual Property Organisation (WIPO) Treaties. ${ }^{10}$ These treaties, discussed below, include recommended measures which are aimed at protecting the "little player" in the intellectual property protection game, like moral rights and performers' rights. New Zealand is a "little player" in the production of intellectual property assets. It is a nett user of such assets. As a "little player" New Zealand should consider the benefits of some of these measures.

\section{The Politics of Intellectual Property Reform}

Intellectual Property is a large and complicated area of law and policy. However, reform of intellectual property statutes is not something that creates great media attention or from a politician's perspective "wins an election". Some of the cutting edge issues in the field relate to technology issues like digitising copyright works and circulating them in cyberspace. Intellectual Property has certainly received more public attention coinciding with the growth of digital and internet technology and biotechnological matters like the patenting of gene sequences. ${ }^{11}$ Internationally a trend is emerging to call intellectual property something spicier in order to attract attention. In the United States one of the latest copyright statute was "pompously titled" ${ }^{12}$ The Digital Millennium Copyright Act. ${ }^{13}$

7 Such films were classified as cinematographic works, s14 Copyright Act 1962 (repealed). These works were known as "Other Subject Matter" and a such did not require originality.

8 Trade Related Aspects of Intellectual Property Rights Agreement (Annex 1C, World Trade Organisation, Marrakesh Agreement) signed 15 April 1994 and came into effect 1 January 1995 (TRIPs).

$9 \quad$ (29 November 1994) 517 NZPD 5224-5225.

10 See $<$ http: / / www.wipo.org $>$ for an explanation of WIPO and its activities.

11 This is a large area beyond the scope of this article. For a general discussion see Philip Grubb Patents for Chemicals, Pharmaceuticals and Biotechnology (Clarendon Press, Oxford,1999).

12 Jane C Ginsburg "Copyright Use and Excuse on the Internet" (2000) 24 Columbia VLA Journal of Law and the Arts 1, 1.

$13 \quad 17$ USC $\S 1201$. 
Populist titles are applied to intellectual property in the technological world. A reference to the "Law of Cyberspace" causes ears to prick up and heads to turn. A politician who can claim to have done substantive work towards reforming the law of cyberspace will undoubtedly receive more populist credibility than one who claims to have lead the charge in intellectual property law reform. However, there is no more a law of cyberspace than there is a law of the horse. I borrow this analogy from the United States $7^{\text {th }}$ Circuit Court of Appeals Judge Frank Easterbrook. Judge Easterbrook stated: ${ }^{14}$

... that the best way to learn the law applicable to specialized endeavors is to study general rules. Lots of cases deal with sales of horses; others deal with people kicked by horses; still more deal with the licensing and racing of horses, or with the care veterinarians give to horses, or with prizes at horse shows. Any effort to collect these strands into a course on 'The Law of the Horse' is doomed to be shallow and to miss unifying principles. Teaching 100 percent of the cases on people kicked by horses will not convey the law of torts very well. Far better for most students - better, even, for those who plan to go into the horse trade - to take courses in property, torts, commercial transactions and the like, adding to the diet of horse cases a smattering of transactions in cucumbers, cats, coal, and cribs. Only by putting the law of the horse in the context of broader rules about commercial endeavors could one really understand the law about horses.

Now you can see the meaning of my title. When asked to talk about 'Property in Cyberspace', my immediate reaction was, "Isn't this just the law of the horse?" I don't know much about cyberspace; what I do know will be outdated in five years (if not five months!); and my predictions about the direction of change are worthless, making any effort to tailor the law to the subject futile. And if I did know something about computer networks, all I could do in discussing "Property in Cyberspace" would be to isolate the subject from the rest of the law of intellectual property, making the assessment weaker.

This leads directly to my principal conclusion: Develop a sound law of intellectual property, then apply it to computer networks.

This last sentence summarises the thrust of this article. Develop a sound law of intellectual property before grappling with new technologies and other current intellectual property issues.

\section{WHAT MAKES SOUND INTELLECTUAL PROPERTY LAW?}

Intellectual property law is sound if it reflects a policy of benefit to those whose activities are governed by it. To date this approach has not always been evident in New Zealand. In the area of patent law the courts follow international trends without detailed 
analysis of what is in New Zealand's best interests. ${ }^{15}$ The uncircumscribed definition of patentable invention leaves the court's in a position to do this. ${ }^{16}$ Copyright law also provides examples. New Zealand has followed the United Kingdom's lead in its attitude towards moral rights. It has placed extreme limitations on moral rights without any apparent analysis of the function of moral rights in New Zealand. ${ }^{17}$ Another questionable approach to law reform in the intellectual property field is whether it is sound to change parts of intellectual property law when an overall policy is not clear.

One of the most dramatic intellectual property reforms, since the 1994 amendments to comply with TRIPs, occurred in 1998. This was to allow the parallel importing of copyright goods. ${ }^{18}$ The political motivation behind this move was undoubtedly to impress the voters by lowering the costs of certain goods. Copyright's prevention of parallel importing was treated as a barrier to free-trade which increased the price of consumer goods. This particular accusation could be levelled at all intellectual property law. If lowering the costs for consumers is to trump other considerations then other areas of other intellectual property laws could be repealed on the same basis. However, this does not occur because other policy issues are at a play. ${ }^{19}$ Intellectual property rights are often recognised as a necessary corollary to free trade. The very existence of TRIPs as part of the WTO illustrates this point. ${ }^{20}$ I do not intend to discuss fully this reform except to comment in a general way. To reform parallel importing without a clear overall intellectual property law is not only piecemeal, but may have been a mistake as far as local industries are concerned. The current government although not the instigator of the 1998 reform continues to deal with parallel importing as if it is entirely separate from intellectual property as a whole. At least this is the appearance created by the division of ministerial

15 See Daniel Armstrong "The Arguments of Law Policy and Practice Against Swiss-Type Patent Claims" (2001) 32 VUWLR.

16 Patents Act 1953, s 2: "Invention" means any manner of new manufacture the subject of letters patent and grant of privilege within section 6 of the Statute of Monopolies and any new method or process of testing applicable to the improvement or control of manufacture; and includes an alleged invention: and "The Statute of Monopolies" means the Act of the 21 st year of the reign of King James the First, chapter 3, intitled "An Act concerning monopolies and dispensations with penal laws and the forfeiture thereof".

17 This is discussed below.

18 Copyright Amendment Act 1998, incorporated into Copyright Act 1994.

19 For a discussion on the competing policies of parallel importing see Matthew J Coull "New Zealand's Approach to Parallel Imported Goods" (1999) 29 VUWLR 253.

20 A similar approach is taken by the European Union in the Treaty of Rome (the founding document of the European Economic Community) arts 85 and 86 . 
responsibility, one Associate Minister is responsible for intellectual property in general and another for parallel importing. ${ }^{21}$

There are some areas of intellectual property where the optimum policy may be hard to pinpoint. Examples of policy precision problems were discussed by Judge Easterbrook in the passages following the above quote: ${ }^{22}$

Problem: we do not know whether many features of existing law are optimal. Why seventeen years for patents, a lifetime plus some for copyrights, and forever for trademarks? Should these rights be strengthened or weakened? Why does copyright have the particular form it does? What sense can one make of the fuzzball factors for fair use? How can one make these rights more precise, and therefore facilitate Coasean bargains? Until we have answers these questions, we cannot issue prescriptions for applications to computer networks.

Cyberspace reduces the effective cost of copying. This continues a trend that began when Gutenberg invented movable type and gave rise to political demand for what has become copyright law. Yet how can we tackle the question whether copying has become too easy, and therefore should be met by countervailing changes, when we have not solved the problems posed by yesterday's technology? Consider the plain-paper photocopier. People can run off scholarly articles. To what extent may researchers copy articles from increasingly expensive journals to create a stockpile for their own future endeavors? This is a question about fair use; yet the fair-use criteria are so ambulatory that no one can give a general answer.

These sorts of difficulties will continue to confound judges, law makers and those who seek to advise others of the law. However, such difficulties alone are not an excuse for failing to coordinate New Zealand's intellectual property policy in a direction which benefits New Zealand. Whatever that direction is it must take into account the subject matter of intellectual property.

The subject matter of intellectual property law ought to impact directly on the policy behind the law. Intellectual property is one of many laws that affect the arts and science and technology. Intellectual property law ought to reflect and promote the government's policy in these areas. The current government has stated a desire to encourage these endeavours. ${ }^{23}$ If a nation needs to move towards a "knowledge economy"24 it must ensure

21 Telephone advice from Parliament 18 December 2000.

22 Easterbrook, above n 14, 208.

23 Prime Minister Helen Clark announced funding of over $\$ 80$ million into the arts, culture and heritage scetor, see <www.executive.govt.nz/minister/clark/arts/index.html $>$ (last accessed 21 February 2001. 
that the laws which vest control and ownership over knowledge based assets are appropriate for the nation in question. New Zealand's law makers must also ensure that intellectual property laws are consistent with the principles of the Treaty of Waitangi. In addition, international agreements commit New Zealand to provide certain minimum intellectual property rights.

\section{NEW ZEALAND'S INTELLECTUAL PROPERTY COMMITMENTS}

New Zealand has two major commitments which should play a significant role in shaping its intellectual property laws. These are the Treaty of Waitangi and various international agreements.

\section{A Treaty of Waitangi ${ }^{25}$}

The Treaty of Waitangi places an obligation on the Crown to protect, amongst other things, Maori taonga. The Treaty guarantees Maori "tino rangitiratanga"; authority on indigeonous flora and fauna. The extent of that obligation as it relates to intellectual and cultural property is the subject of a dispute before the Waitangi Tribunal. ${ }^{26}$

One possibility is that New Zealand should have a cultural property system which operates alongside the current intellectual property structure. The Maatatua Declaration issued by Maori calls for this. ${ }^{27}$ Another possibility is that aspects of the current structure may have to be altered to address Maori concerns. An example of this is the additions recommended by the Ministry of Commerce (now Ministry of Economic Development) to address Maori concerns relating to trade mark registration. ${ }^{28}$

In addition to honouring the Treaty of Waitangi New Zealand's intellectual property law should benefit New Zealand. The internal intellectual property policy should also reflect that New Zealand is bound by international treaties. New Zealand implements its international commitments by statute. For the most part it does not incorporate the treaties directly into the law, but it drafts the law to accord with its obligations.

The term "knowledge economy" is increasingly used by the government: see, for example, Paul Swain "Victoria University Information Policy Summit" at <http://www.executive.govt.nz/ speech /> (last accessed 20 February 2001).

25 The Treaty of Waitangi is an agreement between the Maori people of New Zealand and the Crown which was concluded in 1840 .

26 The claim is known as Wai 262.

27 Maatatua Declaration on Cultural and Intellectual Property Rights of Indigenous Peoples at $<$ http: / / w w w.tpk.govt.nz/mataatua / mataeng1.html $>$ (last accessed 20 February 2001).

28 Ministry of Commerce Maori and Trade Marks: a Discussion Paper (Wellington, 1997). 


\section{B International Commitments}

There are two main international organisations which administer the international agreements to which New Zealand belongs; the World Trade Organisation (WTO) and the World Intellectual Property Organisation (WIPO). The WTO administers TRIPs. As part of the WTO it is immediately apparent that the policy behind TRIPs is to support the trade principles of the WTO. ${ }^{29}$ These can be summarised as free-trade and removal of trade barriers.

The TRIPs agreement incorporates some aspects of certain WIPO agreements and therefore there is an agreement between WTO and WIPO to administer this overlap. ${ }^{30}$ TRIPs incorporates treaties on copyright ${ }^{31}$, trade marks and patents. ${ }^{32}$ It also adds to those treaties. For example, by requiring rental rights in relation to films and computer programmes. ${ }^{33}$ In addition, it requires protection of geographical indications, ${ }^{34}$ industrial designs, ${ }^{35}$ layout designs of integrated circuits, ${ }^{36}$ protection of undisclosed information. ${ }^{37}$ and certain controls of anti-competitive licensing practices. ${ }^{38}$ The function of these international intellectual property treaties is to ensure consistent minimum standards of protection between trading nations. TRIPs states that it provides minimum standards and that it is open to member countries to give increased protections, provided any increased protection does not contravene the provisions of TRIPs. ${ }^{39}$ On the other hand, in some treaties there are provisions which permit a nation to opt out of a particular part of a

See $<$ http: / / ww w. wto.org $>$ for an outline of the WTO.

WTO-WIPO Co-operation Agreement, World Trade Organisation, Geneva 22 December 1995 at $<$ http://www/wipo.org> (last accessed 20 February 2001).

Article 9(1) incorporates arts 1-21 of the Berne Convention for the Protection of Literary and Artistic works, Paris Revision, 10 October 1974 ("Berne").

Article 2(1) incorporates arts 12 and 19 of the Paris Convention for the Protection of Industrial Property, Stockholm Revision 14 July 1967 and as amended on 2 October 1979 ("Paris").

TRIPs, above n 8, art 11 .

TRIPs, above n 8 , section 3 .

TRIPs, above n 8, section 4. New Zealand protects industrial designs by the Design Act 1953 and the Copyright Act 1994.

TRIPs, above n 8, section 6. This requirement led to the Layout Designs Act 1994.

TRIPs, above $\mathrm{n} 8$, section 7. Undisclosed information may be protected by the doctrine of breach of confidence or in cases where the information is embodied in a copyright work protection may arise via the Copyright Act 1994.

TRIPs, above $\mathrm{n} 8$, section 8 .

TRIPs, above n 8, art 1(1). 
treaty. An example of this is the droit de suite (the artist's resale right) provision in the Berne Convention. ${ }^{40}$

An example of giving increased protection is provided by the approach to database protection. TRIPs provides that member states shall protect under copyright laws databases or compilations that involve an intellectual creation. ${ }^{41}$ It is arguable that it would infringe this provision if a member's copyright law extended to protect the more mundane of databases, which involve labour and/or investment rather than "intellectual creation". However, if the "non-intellectual creation" databases are protected independently of copyright this arguably does not contravene TRIPs. This is exactly the approach of the European Union. ${ }^{42}$ It protects these non-intellectual creations by sui generis intellectual property right, which provides a remedy against unfair extraction. Prior to this European Union approach taking effect, the United Kingdom protected the "non-intellectual creation" databases through copyright. ${ }^{43}$ It is arguable that New Zealand law also lends protection to these non-intellectual databases through copyright. At least one High Court judge, McGechan J, has held that the position is not clear in New Zealand. ${ }^{44}$ With respect, I consider the position is clearer than McGechan J suggested. New Zealand has consistently applied a very low standard of originality to give copyright protection. ${ }^{45}$ I do not intend to flesh out this debate in this article. However, what this example demonstrates is that any member of TRIPs can provide additional intellectual property protection appropriate to its local interests. The protection of databases which are not intellectual creations may be regarded as matters in the United States and the European Union's economic interests. ${ }^{46}$

Thus a country, like New Zealand, can and should provide protection appropriate to its economy as long as it does not infringe the international agreements.

40 Berne, above n 31, art 14 ter.

41 TRIPs, above n 8, art 10(2).

42 The Legal Protection of Databases (11 March 1996) EC Directive 99/9/EC.

43 Waterlow Directories, above n 5.

44 Telecom v Yellow Pages (14 August 1997) unreported, High Court, Wellington Registry, CP $142 / 97,16$.

$45 \quad$ Frankel, above n 5. 


\section{Minimum International Requirements for Copyright and Related Rights}

\section{Current New Zealand copyright and related rights treaty obligations ${ }^{47}$}

New Zealand has committed to protect certain types of works as copyright works. These include literary, artistic, musical and dramatic works, films, sound recordings and broadcasts. ${ }^{48}$ Computer programs must be protected as literary works. ${ }^{49}$

The Berne Convention (incorporated into TRIPs ${ }^{50}$ ) provides that certain works, which primarily fall within the definition of "literary", may have limits on their protection. ${ }^{51}$ These are: (a) official texts of a legislative, administrative and legal nature and official translations of such texts; 52 and (b) works of applied art and industrial designs and models. ${ }^{53}$ New Zealand protects these works under the Copyright Act 1994, but in relation to (a) it allows substantial permitted $\mathrm{uses}^{54}$ and in relation to (b) provides a shorter duration of protection. ${ }^{55}$

New Zealand also protects cable programmes ${ }^{56}$ and typographical arrangements of published editions. ${ }^{57}$ There are no international obligations to protect these categories of work.

47 This section summarises aspects of the major agreements. It is not intended to be an exhaustive list of all international copyright commitments.

48 TRIPs, above $\mathrm{n} 8$ and Berne, above $\mathrm{n}$ 31. The broadcast category of work received international protection from the Rome Convention for the Protection of Performers, Producers of Phonograms and Broadcasting Organizations, Rome on 26 October 1961. New Zealand is not a member of the Rome Convention. However, the obligations it creates in terms of categorisation are also obligations under TRIPs, above $\mathrm{n} \mathrm{8,} \mathrm{art} \mathrm{14,} \mathrm{to} \mathrm{which} \mathrm{New} \mathrm{Zealand} \mathrm{is} \mathrm{a} \mathrm{party.} \mathrm{In}$ addition, New Zealand provides protection at a level which meets the requirements of the Rome Convention. New Zealand is a member of the Geneva Phonograms Convention 1971 which was established to combat record piracy with the advent of the tape recorder. The Convention was established alongside the Rome Convention as a more palatible version. See Sterling World Copyright Law (Sweet \& Maxwell, London, 1998) para 1.22.

TRIPs, above n 8, art 10(1).

TRIPs, above n 8, art 9

51 Berne, above n 31, art 2(1).

52 Berne, above n 31, art 2(4).

53 Berne, above n 31, art 2(7)

54 Copyright Act 1994, ss 58-66.

55 Copyright Act 1994, s 75 reduces the term of protection for artistic works which have been industrially applied to 15 years. This makes the term of protection equivalent to registered design protection under the Designs Act 1953 
The TRIPs agreement incorporates the Berne Convention definition of "literary and artistic works". This includes musical works, dramatic works and films. ${ }^{58}$ In addition, TRIPs requires protection of broadcasts, ${ }^{59}$ computer programs ${ }^{60}$ and "compilations of data or other material, whether in machine readable or other form, which by reason of the selection or arrangement of their contents constitute intellectual creations". ${ }^{61}$ It also provides for minimal protections for performers from having their performance recorded or copies of those illicit recordings distributed. ${ }^{62}$

\section{Copyright and related rights treaties to which New Zealand does not belong}

(a) WIPO Copyright Treaty $1996^{63}$

This Treaty exists independently of the Berne Convention and is not incorporated into TRIPs. It makes reference to the Berne Convention, but has been formulated so that members of Berne are free not to sign up to it. It is not an amendment of the Berne Convention, but is an optional protocol to it. ${ }^{64}$ This Treaty is directed towards copyright protection in the face of new technologies. It provides for a number of new rights, including a broad communication right, ${ }^{65}$ which is directed to exploitation of works in the digital internet world. ${ }^{66}$

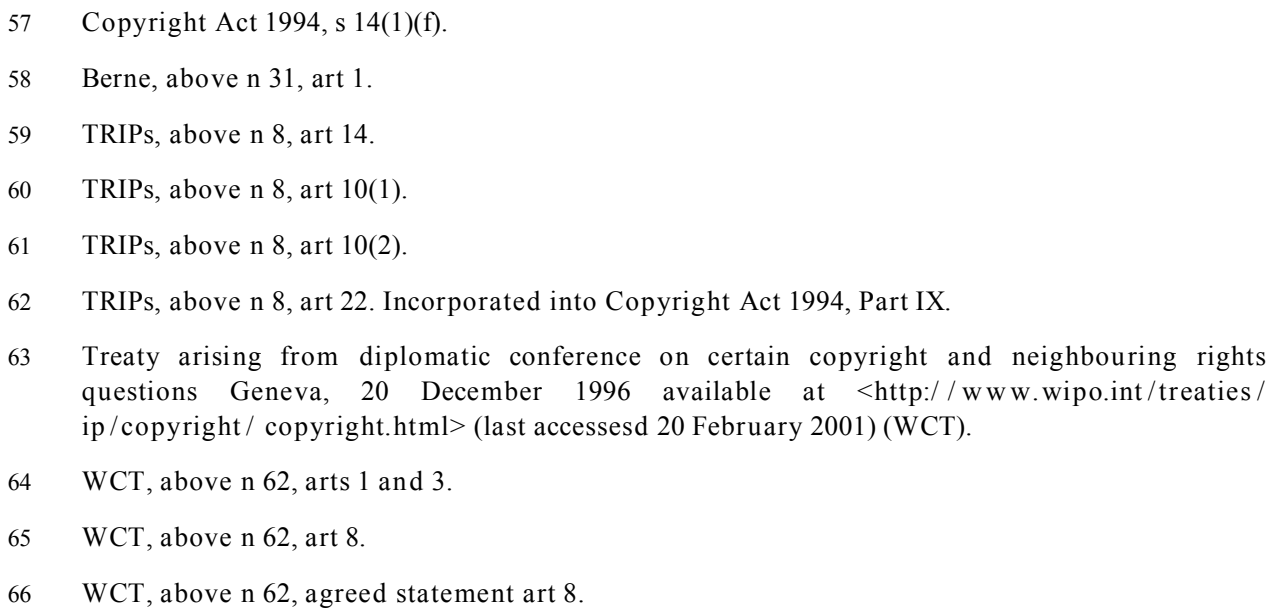


(b) WIPO Producers of Phonograms and Sound Recordings Treaty $1996^{67}$

This Treaty recommends the introduction of economic rights for performers and producers of phonograms. These rights are along the lines of the exclusive rights of copyright in relation to other works. In effect it provides for a new category of work, "the performance". It also recommends the introduction of moral rights for performers. ${ }^{68}$ These are discussed below.

The use of the term phonogram is not intended to limit the rights to old technologies. The term is defined to incorporate modern technologies. ${ }^{69}$

D Minimum International Requirements for Trade Marks and Geographical Indications ${ }^{70}$

\section{TRIPs}

The TRIPs agreement provides that members "shall protect any signs capable of distinguishing the goods or services from one undertaking from those of other undertakings". ${ }^{71}$ Trade mark owners are given the exclusive rights to prevent third parties from using the signs in specified circumstances. ${ }^{72}$ The members of TRIPs also agree to give certain protections for well known marks in relation to goods and services. ${ }^{73}$ Well known marks in relation to goods received protection under the Paris Convention. ${ }^{74}$

67 Treaty arising from diplomatic conference on certain copyright and neighbouring rights questions, Geneva, 20 December $1996<\mathrm{http}$ //www.wipo.int/treaties/ip/performances/ performances.html > (last accesses 20 February 2001) (PPT).

PPT, above n 67 , art 5 .

69 PPT, above $\mathrm{n}$ 67, art 2 states "phonogram" means the fixation of the sounds of a performance or of other sounds, or of a representation of sounds, other than in the form of a fixation incorporated in a cinematographic or other au diovisual work.

70 This is a summary of the main agreements. It is not intended to be an exhaustive list. WIPO administers a Trademark Law Treaty to which New Zealand does not belong. The text of the treaty is available at <http://www.wipo.int/treaties/ip/trademark-law/index.html > (last accessed 20 February 2001).

71 TRIPs, above $\mathrm{n} 8$, art 15(1).

72 TRIPs, above $\mathrm{n} 8$, art 16(1).

73 TRIPs, above $\mathrm{n} 8$, art 16(2).

74 Paris, above $\mathrm{n} 32$, art 6 bis. 


\section{Paris Convention for the Protection of Industrial Property $1883^{75}$}

This Convention provides very few substantive law provisions, but it is the basis of important agreement on a number of procedural matters. It has been revised a number of times. The few substantive law provisions relate to protection of well known marks, protections of state emblems, official hallmarks and the like ${ }^{76}$ and protection of service marks. ${ }^{77}$ The main procedural aspects of the Convention are summarised here:

- All members of the Convention must provide equal protection to trade marks owned by nationals of other member countries. This is known as national treatment. ${ }^{78}$

- The domestic law of each member nation governs protection in its territory. ${ }^{79}$

- Nationals from all members have a right of priority in other member countries provided an application is made in that country within six months from the date of the first filing. ${ }^{80}$

- The nature of goods to which applied must not prevent registration. ${ }^{81}$

- Seizure of goods with unlawful marks. ${ }^{82}$

- General unfair competition protections. ${ }^{83}$

\section{Nice Agreement on the Classification of Goods ${ }^{84}$}

All trade and service marks are registered in respect of a class of goods or services. It would be difficult, if not impossible, to co-ordinate international registration unless the same categories of goods or services are used by all trade mark registries. This agreement provides a standard for classification of goods and services.

75 New Zealand is an original signatory and a member of the London Revision on 2 June 1934 and Stockholm Revision of 14 July 1967.

76 Paris, above n 32, art 6 ter.

77 Paris, above n 32, art 6 sexies.

78 Paris, above n 32, art 2(1).

79 Paris, above n 32, art 6.

80 Paris, above $\mathrm{n} 32$, arts $4 \mathrm{~A}$ and $4 \mathrm{C}$.

81 Paris, above n 32, art 7.

82 Paris, above $\mathrm{n} 32$, arts 9 and 10.

83 Paris, above $\mathrm{n}$ 32, arts 10 bis and 10 ter.

84 New Zealand is not a member of this agreement but complies with it. 


\section{E Minimum Requirements for Patents and Plant Varieties}

\section{TRIPs}

TRIPs requires that patent protection is made available for all areas of technology. ${ }^{85} \mathrm{~A}$ member may make exceptions on the grounds of morality and in relation to humans, plants and animals. Articles 27(2) and 27(3) provide:

2. Members may exclude from patentability inventions, the prevention within their territory of the commercial exploitation of which is necessary to protect ordre public or morality, including to protect human, animal or plant life or health or to avoid serious prejudice to the environment, provided that such exclusion is not made merely because the exploitation is prohibited by domestic law.

3. Members may also exclude for patentability:

(a) diagnostic, therapeutic and surgical methods for the treatment of humans or animals;

(b) plants and animals other than microorganisms, and essentially biological processes for the production of plants or animals other than non-biological and microbiological processes.

TRIPs also requires protection of plant varieties either by patent or sui generis right. ${ }^{86}$

\section{Paris Convention for the Protection of Industrial Property $1883^{87}$}

This Convention does not provide much in the way of substantive rights for patents, ${ }^{88}$ although it sets out a number of procedural rights. It provides the mechanism by which foreigners can access other members patent regimes. Importantly it requires:

- National treatment for patent owners. ${ }^{89}$

- A patent applicant has 12 months from the date of first filing a patent to obtain priority in another member country by filing an application there. ${ }^{90}$

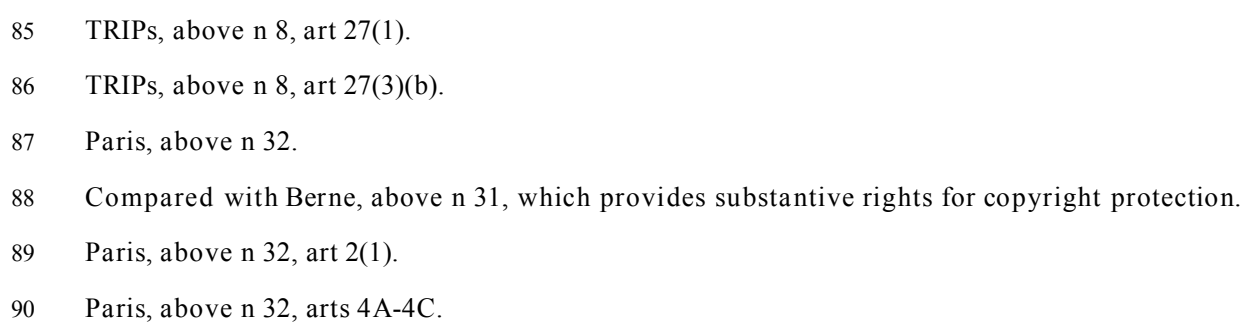




\section{The Patent Co-operation Treaty ${ }^{91}$}

This treaty provides a mechanism by which there are agreed procedures for the initial stages of making a patent application. This is to smooth the process of patent applications getting of the ground before national specific laws, which may vary considerably between members, govern the process.

\section{Union for the Protection of New Varieties of Plants 1962 (UPOV)}

Because of the TRIPs requirement for plant varieties protection UPOV has received a boost into the limelight. New Zealand's Plant Varieties Act 1987 is based on the 1987 UPOV revision to which New Zealand is a signatory. New Zealand is also a signatory to the 1991, but has not yet amended its Plant Varieties Rights Act accordingly. ${ }^{92}$ There is no time limit on when the revision must be complied with. The outcome of the Waitangi Tribunal proceedings relating to Maori claims over flora and fauna may well have an impact on future legislation. Waiting is therefore a necessity.

\section{Rio Convention on the Preservation of Biological Diversity $1992^{93}$}

The main aims of the convention are: ${ }^{94}$

- $\quad$ To conserve biological diversity;

- To make sustainable use of biological resources; and

- $\quad$ To fairly share benefits arising from utilisation of genetic resources.

It is debateable whether these goals are compatible with the TRIPs agreement. This matter has yet to be settled on a global scale. ${ }^{95}$

New Zealand's current government is implementing a biodiversity strategy to "prevent the extinction and promote the restoration of our endangered native species."96

91 New Zealand is a signatory to this treaty.

92 For a discussion of the requirements for compliance with the 1991 revision see Lucy Walls "Plant Variety Rights, Biodiversity Obligations and the Protection of New Zealand's Native Plant Resources - Are They Compatible ?" (LLB (Hons) paper, Victoria University, 1 September 1997).

93 The Rio Convention was ratified by New Zealand in September 1993 and it came into force in December 1993. Available at <http: / / www.unep.ch/bio/conv-e.html> ("Rio").

94 Rio, above n 92, art 1.

95 Reid and Miller Keeping Options Alive: The Scientific Basis for Conserving Biodiversity (World Resources Institute, USA, 1998). 


\section{NEW ZEALAND'S COPYRIGHT POLICY}

\section{A Copyright Economic Rights}

New Zealand copyright law broadly described protects the arts and industrial design. It has evolved to give protection to sound recordings, films, broadcasts, cable programmes, computer programmes, databases and the like. ${ }^{97}$

Historically copyright has justified itself on the basis of encouraging the dissemination of knowledge by protecting authors and providing them with an incentive to create new works. The United Kingdom's first copyright statute, the Statute of Anne 1710, was entitled "An Act for the Encouragement of Learning by Vesting the Copies of Printed Books in the Authors or Purchasers of Such Copies". ${ }^{98}$ The encouragement of authors and creators remains a justification for copyright laws, even though in today's world copyright ownership and control is often in the hands of commercial entities. The Statute of Anne provided for and anticipated development of authors transferring their rights by "purchase".

Even though authorship and ownership are separate concepts modern copyright disputes such as $A \& M$ Records Inc $v$ Napster Inc ${ }^{99}$ can be interpreted as a victory for authors. Napster decided that music producers were entitled to control the dissemination, via the internet, of digital sound recordings compressed in MP3 format. The ability to retain control over all copying of works is an authorial victory, even though the authors assigned their works to the record companies. To the public Napster may have the appearance of the heavy hand of copyright slamming down on the wide spread use of MP3. If viewed in this way, sight of the authorial victory is easily lost. Napster illustrates the classic copyright conflict between how far the rights of ownership should extend to circumscribe the rights of users. Or viewed from another perspective, how much should user convenience should triumph at the expense of a copyright owner.

The international treaties summarised above direct themselves to protecting not only authors, but the commercial entities which produce copyright works. New Zealand is a nett user of copyright works. As such, where possible, New Zealand should adjust its laws

96 Funding for the Biodiversity Strategy was announced by Hon Sandra Lee, Minister of Conservation, <http://www.executive.govt.nz/minister/lee/biodiversity/index.html > (Last accessed 20 February 2001).

Copyright Act 1994, s 14.

98 Statute of Anne $1710(\mathrm{~GB}), 8$ Anne, c 18.

99 A\&M Records Inc v Napster Inc (2001) 239 F 3d 1004, 57 USPQ 2d 1729 (7th Cir) (Napster). 
to benefit its status as nett users of copyright works. There are a number of ways to achieve this.

\section{Exclusive rights}

An exclusive copyright right, which is a benefit to the creators in the field of fine arts, is the droit de suite. The droit de suite translates to the artists' resale right. The right is not a "pure copyright" right, but it is a kind of distribution right.

Copyright grants owners many exclusive rights, including the right to first distribution of a copyright work. In New Zealand this is known as the right to issue the work to the public. ${ }^{100}$ The right to issue works to the public only gives copyright holders the right to control the placing of first copies on the market. An exception to this is the rental right. ${ }^{101}$ In New Zealand rental rights are exclusive rights in respect of computer programs and films. Another possible extension of the right to issue works to the public, is the droit de suite. To date New Zealand has not incorporated the droit de suite in its copyright law.

The droit de suite gives the artist of a work of fine art, like a painting or sculpture, a right to remuneration every time the artist's work is resold. The right is available in France, Germany and in many civil law countries of Europe and Latin America. ${ }^{102}$ The philosophy behind the droit de suite lies in providing a means for reasonable remuneration to such artists. Many copyright works, for example some literary works and sound recordings, provide their owners with financial rewards by the sale of many copies. The ability to control the manufacture of multiple copies is the purpose of copyright. Works of fine art can be distinguished from other copyright works because they do not rely on multiple copies to make a profit. Copyright ownership is still important for these works because it stops others from making multiple copies. However, the value of the work lies in the fact it is the only copy or one of very few copies. The droit de suite is a mechanism of providing remuneration and therefore an incentive for artists to continue to create. This incentive to create is part of the theoretical justification for copyright law. ${ }^{103}$

In practice the droit de suite requires careful organisation, so that collections costs do not make it unworkable. ${ }^{104}$ This issue is the same for any royalties collecting society. New

$100 \quad$ Copyright Act 1994, s 9.

101 Copyright Act 1994, s 9(2).

102 The United States has identified thirty-six countries as having a droit de suite: see United States Copyright Office "Droit de Suite: The Artist's Resale Royalty - Executive Summary" (1992) 16 Columbia VLA J L \& Arts 381, 382.

103 See Susy Frankel "Protecting 'Killer Crocs' and 'Fantasy Football': the Ethics of Copyright Law" (1998) 28 VUWLR 191, 192-193. 
Zealand should consider implementing the droit de suit. One function of the droit de suite is that it supports local talent. For a country like New Zealand it may well be beneficial to support our local artists in this way. To do so would not infringe any international agreements. The Berne Convention provides for the droit de suite. ${ }^{105} \mathrm{It}$ is one of the few articles of the convention which is voluntary. In not providing a droit de suite New Zealand has followed the United Kingdom and United States common law country line. There is a proposal for a droit de suite before the European Union. ${ }^{106}$ If the European Union implements the proposal the United Kingdom will have to legislate for a droit de suite. New Zealand should consider providing this local incentive to our artists. The government should at least weight up the pros and cons and throw it open for public debate. ${ }^{107}$ The droit de suite may well benefit New Zealand artists.

The exclusive rights of the copyright owner are largely enshrined in the international agreements discussed above. It would be difficult and undesirable in most cases to alter these. However, these rights may be modified to best serve New Zealand via permitted uses.

\section{Permitted uses}

There could be more flexible permitted uses of copyright works. The Copyright Act 1994 permits uses of copyright works in certain circumstances. These circumstances include research and private study, criticism or review or education. ${ }^{108}$ The Berne Convention requires that such permitted uses do not conflict with the normal rights of exploitation of the owner of the copyright. ${ }^{109}$ New Zealand has adopted its approach to permitted uses almost entirely from the United Kingdom Copyright, Designs and Patents Act $1988 .{ }^{110}$ It is often argued that the better approach to permitted uses is that of the United States. There the doctrine, known as fair use, is dictated by general factors, such as the nature and purpose of copying the work, rather than specific purposes such as

105 Berne, above n 31, art 14 ter.

106 European Commission "Proposed Directive on Artists' Resale Right - Latest Developments" < http: / / europa.eu.int/comm/internal_market/en/intprop/news/artresale.htm> (last accessed 19 February 2001).

107 This has been done in the United Kingdom see: for the United Kingdom Patent Office Droit de Suite in the United Kingdom: A Study of the Impact of the Proposed Harmonisation of EC Artist Resale Rights Levies on the United Kingdom Art Market (MTI Consultants, London, 7 April 1999).

108 Copyright Act, Part III, ss 40-93.

109 Berne, above n 31, art 9(2).

110 One notable exception is s 43 of the Copyright Act 1994 which draws heavily on United States law. See 17 USC $\S 107$. 
education and research. ${ }^{111}$ It is not my intention to explore the pros and cons of those different approaches, but rather to reflect on the appropriateness of specific outcomes of New Zealand's permitted uses policy.

A common criticism of the purpose prescribed permitted uses approach is that it fails to assist the development of arts and culture in the field of parody. ${ }^{112}$ The comedian who parodies a copyright work and in doing so has copied a substantial part of the work cannot be assured that this will not result in a less humorous lawsuit. Again I do not propose traversing the details of the parody debate, I raise it to point out that there is no obvious reason for New Zealand to maintain such an anti-parody stance. We have inherited it from the United Kingdom, but is it appropriate for New Zealand in the $21^{\text {st }}$ century?

Another problem with our current paradigm of permitted uses is the increased cost it places on New Zealanders to use copyright works. Since the 1994 Act it has cost educational institutions and those who participate in them considerably more to copy literary works for teaching or study purposes. ${ }^{113}$ Permitted uses exist, but they are very limited. For example, potentially if a student copies an article for her studies and decides to make a second copy for a fellow student the permitted uses are unlikely to extend to allow that second copy. ${ }^{114}$ It can only be made by the student who actually uses it for research or private study. While that student is unlikely to be sued for that infringement it illustrates that our permitted uses are very, and arguably unnecessarily, narrow in scope. How does the making of an extra copy for a friend "conflict with the normal exploitation of the work". ${ }^{115}$ It does not. The purpose behind these very limited permitted uses appears to be to encourage the growth of collecting societies. These organisations collect royalties, both large and small, on behalf of copyright owners. The royalties are then distributed to the owners. Such societies succeed on the basis that they are more efficient for users and right holders. The societies have been around for some time in relation to music, but the

11117 USC $\S 107$. For its application see American Geophysical Union v Texaco Ltd (1994) 29 IPR 381 (2nd cir).

112 For a discussion on the nexus of parody and copyright see Hugh Laddie, Peter Prescott and Mary Vitoria The Modern Law of Copyright and Designs (2 ed, Butterworths, London, 1995) para 2.113-2.114.

113 I cannot provide statistics of any amounts. However, an increase must have occurred as educational institutions pay now for what may have in some cases been free, by virtue of section 19 of the Copyright Act 1962.

114 Copyright Act 1994, s 43(4) provides that only one copy of a work can be made on any one occasion.

115

Berne, above n 31, art 9(2). 
Copyright Act 1994 has encouraged their development. Since 1994 New Zealand has seen the rise of collecting societies in the areas of literary works and audio visual works.

The limits on permitted uses illustrated by the student copying example above, seem particularly draconian for a country that imports a major proportion of its literary works. The parties who stand to gain from this are mostly not New Zealanders. New Zealand cannot discriminate in its protection between local and foreign works. This would violate the principle of national treatment, which is enshrined in the Berne Convention and TRIPs. ${ }^{116}$ Indeed I do not suggest that such material reciprocity would be desirable, but New Zealand should learn a lesson from the major world players. The United States and the European Union foster copyright laws which help their locals. Where permissible, without infringing international agreement New Zealand should do the same.

Even where New Zealand produces some copyright works adjustments to permitted uses could help that production. For example, New Zealand does not expressly provide a permitted use to reverse engineer a computer program in any circumstances. ${ }^{117}$ This is in stark contrast to the United States. The United States has allowed fair use to protect the reverse engineering of computer programs, if the purpose of that reverse engineering is to make computer program that is interoperable with the program which has been reverse engineered. ${ }^{118}$ Surely software development in New Zealand would benefit from this. The outposts of the software giants may not necessarily be appreciative, but this is a dilemma they face in their own countries. It is not at all clear or justifiable why New Zealand should provide these international giants with stronger intellectual property rights than their own legislatures see fit to provide them with.

Broadly speaking there ought to be permitted uses for education research and study, use in judicial proceedings and other matters where copying is part of the function of activities like broadcasting and cabling. Many domestic copying activities for personal or no commercial use may need to be permitted to avoid making a nonsense of new technologies. Although Napster may be an example of the difficulties in drawing that line. ${ }^{119}$

New Zealand has not been adverse to including very specific permitted uses based on adverse judicial findings. After a news clipping service business failed to establish its news

116 Berne, above n 31, art 5 and TRIPs, above n 8, art 3.

117 Reverse engineering involves making copies that would be infringing copies unless made by virtue of a permitted use.

118 Sega Enterprises Ltd v Accolade Inc (1992) 23 USPQ 2d 1440.

119 Napster, above n 99. 
clipping activity as a permitted use ${ }^{120}$ the solution was a legislative change which allows news clipping services to undertake their activities without infringing copyright. ${ }^{121}$

I believe that New Zealand must conduct its own empirical research to establish an appropriate framework for its own permitted uses.

\section{B Moral Rights}

In 1994 when the Copyright Act 1962 was repealed a new grouping of rights appeared in the Copyright Act 1994, under the heading "moral rights". ${ }^{122}$ This new part of the Copyright Act 1994 was taken directly from the United Kingdom Copyright, Designs and Patents Act 1988. There are four categories of moral rights in New Zealand's copyright legislation. The right to authorship, ${ }^{123}$ the right to object to derogatory treatment of a copyright work, ${ }^{124}$ rights against false attribution ${ }^{125}$ and rights of privacy in relation to certain films and photographs. ${ }^{126}$ The right to authorship and the right to object to derogatory treatment are the core moral rights. They may be claimed by authors of literary, dramatic, musical and artistic works and directors of films. These rights are personal to the authors and exist independently of the economic rights that copyright provides in relation to the works. The rights against false attribution and privacy, of certain films and photographs, are not strictly moral rights because they can be enforced by anyone, ${ }^{127}$ not just authors and directors.

The moral rights provisions were rushed into the Copyright Act 1994 with little debate and virtually no consideration of what New Zealand's policy should be in relation to moral rights. These reforms were part of the 1994 reforms to comply with TRIPs. However, moral rights are expressly excluded form the TRIPs agreement. ${ }^{128}$ There was no obvious

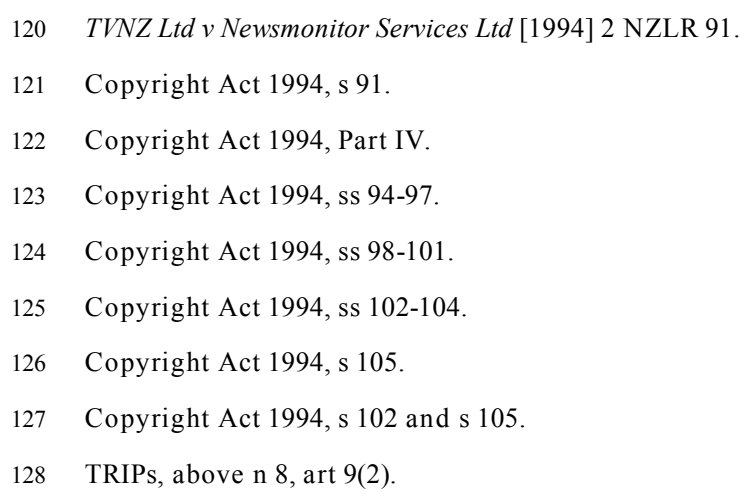


need to rush their introduction. At least, compliance with international agreements did not necessitate their hasty introduction. ${ }^{129}$

The rights to authorship and to object to derogatory treatment have their international origins in the Berne Convention. ${ }^{130}$ The concept of moral rights can be traced to civil law systems, which have developed their copyright laws from the standpoint of authors rights. ${ }^{131}$ The phrase "moral rights" is a bad translation of the French "droit morale". It is a bad translation because "moral" in English has implications of ethics. The rights are said to attach to the author, a creative work is an extension of the author. Thus, a better translation may be "morale rights".

The existing moral rights legislation is severely limited by definitions and by exceptions. ${ }^{132}$ Some of these exceptions are necessary for the functionality of the rights. For example, it does not seem sensible that the right of authorship should be granted to directors of television advertisements. ${ }^{133}$ Imagine a life where there are credits following each advertisement. However, some exceptions and limitations on the rights are more directed at making the rights very limited and arguably virtually ineffectual. Since their introduction in 1994, there has been no substantial litigation on moral rights in New Zealand. Since their introduction in the United Kingdom in 1988, there has been some, but very little substantive litigation. It would be nice to believe that the small amount of dispute reaching the courts reflects that copyright works are rarely derogatorily treated and authors are always acknowledged. However, it is more likely that the limitations of the rights are so severe that they are rarely of much utility.

Any moral rights legislation ought to have a clear policy behind it. A positive policy goal is not evident from the 1994 moral rights paradigm. If anything the policy seems to be to make the rights as insignificant as possible. What the broad rights "giveth" the exceptions "taketh" away. In my opinion, New Zealand had, and still has, a perfect opportunity to support its local copyright producers and to address some aspects of Maori concerns through developing its own moral rights regime.

129 The moral rights provisions went through Parliament without detailed review and without amendments, see (6 December 1994) 545 NZPD 5381.

130 Berne, above n 31, art 6 bis.

131 For a general discussion see Jane Ginsburg "A Tale of Two Copyrights" [1990] Tulane Law Review 991, 993.

132 Each right has two or three pages of parameters of content and exceptions.

133 Copyright Act 1994, s 97(8)(a). 
In particular, the right to object to derogatory treatment is unduly limited in New Zealand. My main challenge is to the definition of treatment. It includes any addition to, deletion from, alteration to or adaptation of. ${ }^{134}$ What it does not encapsulate is the possibility of derogatory treatment by association with, or in a setting of, cultural inappropriateness.

If an artist paints a picture with some cultural or religious significance and it is displayed with other works of art that potentially offend the cultural or religious significance the artist should be able to object to this treatment. For example, the author of a work of religious art may consider it derogatory if the work of art was displayed alongside an exhibition of nudes. I make no judgement on either of these art forms, but use it as an example to illustrate a gap in the current moral rights protection which need not be there. Other examples are where it is inappropriate for a museum or gallery to display a particular work of Maori art in a certain manner, or where a Maori artwork is misused in an advertisement. Moral rights is one area where matters of cultural appropriateness could be addressed through copyright law. I do not suggest that moral rights are the solution to all cultural property issues, but it is one area of our law which could be used to address some of these concerns, without offending any international obligations. One limitation would be whether such rights only applied to copyright works. Arguably cultural protection should apply to matters outside copyright, regardless of whether or not they are protected by another intellectual property right, like trade marks. Limiting the rights to copyright potentially poses another serious limitation. The expiration of copyright is an issue that does not accord with the perspective that the cultural significance of a copyright work remains even if copyright has expired. ${ }^{135}$

In addition to existing moral rights the WIPO Performers and Producers of Phonograms Treaty proposes extending moral rights to performers. ${ }^{136}$ New Zealand should consider the benefits this may afford New Zealand performers. After all New Zealand has a number of performers. There may be aspects of cultural performance protection that could be addressed under these moral rights.

\section{Performers' Rights}

The WIPO Performers and Producers of Phonograms Treaty seeks to give economic and moral rights to performers. In effect this would add a new category of copyright work,

134 Copyright Act 1994, s 98(1)(a).

135 For a discussion of Maori cultural property perspectives see Aroha Mead "Indigenous Rights to Land and Biological Resources" (Paper presented to Institute for International Research, 1994). 
"the performance", and a new category of right holders, "the performer", to the copyright paradigm.

The historic resistance to performers rights has two main bases. First, that performances are not true original copyright works because the performance is merely acting out, and therefore copying, an existing copyright work. This argument is easily rebutted by the fact that performers do put their own interpretation into a performance. It can therefore be said that they exercise skill, judgement and labour in creating their own original copyright work. Moreover, if a performance is a mere copy of an existing work this implies that that any one could do it. If anyone could do it would Julia Roberts and Sam Neil receive their high rates of pay?

The other source of objection to performers' rights usually comes form those who exploit performances: film producers, broadcasters and cable companies. From their perspective performers' rights represent another right to negotiate in an already rights heavy and expensive industry. Increasing the operating costs of these organisations is a potential result of increasing performers' rights protection, but this alone should not stop justifiable rights from protection. In addition, as a small player in the copyright world New Zealand should seek to give maximum protection to small players in the world of film and television, often these are the performers. Particularly those of lesser fame than Sam Neil and Julia Roberts. The policy makers in this area should maximise the bargaining power of our home grown performers.

\section{NEW ZEALAND'S TRADE MARK AND RELATED RIGHTS POLICY}

New Zealand will in the not too distant future consider amendments to the law of trade marks. A trade marks bill is not yet before Parliament but has been drafted. ${ }^{137}$ For that reason any comments about changes to policy may best wait until that bill is public knowledge.

In a broad sense a crucial policy matter for trade marks and it related areas of intellectual property law is the overlap between registered trade marks, passing off and the Fair Trading Act 1986. In a situation where passing off and the Fair Trading Act 1986 provide relief, does that mean the Trade Marks Act should also cover the infringing conduct or vice versa. For example, a mark may not be registered (perhaps because its owners were unaware of the benefits of registration) or because it is not inherently distinctive (say because its primary signification is geographical. ${ }^{138}$ ). In this instance

137 Telephone discussion with Ministry of Economic Development, Intellectual Property Policy Advisor, 18 January 2001.

138 Trade Marks Act 1953, s 14(1) 
should passing off and the Fair Trading Act fill that gap. At present the answer to this example is probably yes. ${ }^{139}$ Another example is provided by the misappropriation of a domain name by a cybersquatter. Trade mark law does not clearly capture this. Passing off has been stretched to fill the gap. ${ }^{140}$ Should trade mark law cover this sort of infringement or does that undo the theoretical foundations of trade mark law in a potentially hazardous way?

Trade mark law is an area which is increasing its catchment. Other papers in this issue consider the pros and cons of that and I could not do them justice by repeating them here. $^{141}$

An important point for the policy makers to remember is trade marks potentially provide indefinite protection. Internationally the trend is to increase trade mark protection. Is following that trend in New Zealand's interest?

\section{NEW ZEALAND'S PATENT LAW AND RELATED RIGHTS POLICY}

The current government has inquiries in relation to biodiversity ${ }^{142}$ and genetic modification. ${ }^{143}$ Whatever the outcome of those proceedings patent law should reflect those policies. One way in which patent law does not currently reflect any policy in relation to scientific endeavours is the definition of patentable invention. As discussed above, this definition is wide and leaves potential for almost anything to fall under the definition. ${ }^{144}$ Nothing in the Patents Act 1953 limits the patentability of any subject matter provided it meets the technical requirements of patentability. ${ }^{145}$ Other nations have found that their definitions of invention also allow policy matters of what is patentable subject matter to be determined by the courts if Parliament has not been express. For example, in

139 See, for example, Wineworths Group Ltd v Comite Interprofessionel du Vin de Champagne [1992] 2 NZLR 327 (CA); Chocosuisse Union des Fabricants Suisses de Chocolat and Others v Cadbury Ltd (1998) 41 IPR 1 (EWHC).

140 British Telecom v One In A Million [1998] 4 All ER 47 (EWCA) and Oggi Advertising v McKenzie Ltd [1999] 1 NZLR 63 (HC); NZ Post v Leng [1999] 3 NZLR 219 (HC).

141 Jacey McGrath "The New Breed of Trade Marks: Sounds, Smells and Tastes" (2001) 32 VUWLR 277 and Rachel Keane "How the Domain Name Scuffles are Rocking the Foundations of Trade Mark Law" (2001) 32 VUWLR 321.

142 See funding for the Biodiversity Strategy <http://www.executive.govt.nz/ minister/lee/biodiversity/index.html > (last accessed 20 February 2001).

143 See Royal Commission on Genetic Modificaiton <http://www.executive.govt.nz/ policies/index.html> (last accessed 20 February 2001).

$144 \quad$ Above n 16.

145 These include novelty. For a general discussion of patentability see William Cornish Intellectual Property: Patents, Copyright, Trade Marks and Allied Rights (2 ed, Sweet \& Maxwell, London, 1989). 
Canada the transgenically altered onco mouse was patentable because the definition of patent did not prevent it from being patented. ${ }^{146}$ I do not want to enter the debate of whether or not genetically altered animals or humans genes should be patented, but to point out that unless clear guidance is provided in by Parliament the Patent Office and the courts are free to patent any subject matter.

Moreover, the position of Maori must be added to this debate. ${ }^{147}$

\section{CONCLUSION}

When reforming intellectual property law it is important that New Zealand understand why it is taking a certain path. International trends alone should not determine policy. The path for New Zealand should be determined by our own best interests. International agreements can be honoured without them dictating every policy direction. Overseas legislation, in particular that of the United Kingdom, should be considered critically in light of differing perspectives and economic considerations in the country of origin. Intellectual property reform must be in accordance with the Treaty of Waitangi.

International agreements allow for local needs to prevail in many, although not all areas. New Zealand should seize the opportunity to develop a sound New Zealand intellectual property law.

146 President and Fellows of Harvard College v (Canada) Commissioner of Patents (4 December 2000) unreported, Canada Federal Court of Canada, A-334-98.

147 For a discussion of some Maori concerns on the patenting of life forms see Ministry of Economic Development Maori and the Patenting of Life Form Inventions (Wellington, 2000). 
